\title{
RELEVANCE OF BAHASA INDONESIA MAIN MATERIALS WITH HOTS (HIGHER ORDER THINKING SKILLS)
}

\author{
Rina Rahmi ${ }^{1}$, Iin Nurhalizha ${ }^{2}$, Nasrin Nabila ${ }^{3}$ \\ Universitas Islam Negeri Sunan Kalijaga Yogyakarta, Indonesia ${ }^{1,2,3}$ \\ E-mail: rina.rahmi23@gmail.com¹, iinnurhalizha11@gmail.com², \\ nnasrinnabila@gmail.com ${ }^{3}$
}

DOI: $\underline{10.14421 / a l-b i d a y a h . v 12 i 1.236}$

\begin{abstract}
This article aims to analyze the relevance of Bahasa Indonesian subject matter revised of 2017 Integrated Thematic book for Grade IV at semester one published by the Ministry of Education and Culture (MOEC) with High Order Thinking Skills (HOTS). This research was conducted because HOTS is one of the necessary skills in the 21st century so that the material of Bahasa Indonesian subject matter in the thematic teaching book must be relevant to HOTS because the teaching material is one aspect that affects the implementation of learning activities. A descriptive qualitative was applied to conduct this study. The primary data source was Thematic Books (both for teacher and student) for semester one at Grade IV of primary school. Data were analyzed using a content analysis based on Bloom's taxonomy theory because the theory makes the level of human thinking level from the lowest to the highest. The results showed 27 indicators that contain HOTS, which are five indicators in theme 1, 3 indicators in theme 2, 6 indicators in theme 3,8 indicators in theme 4, and 5 indicators in theme 5. Bahasa Indonesian subject matter contained in the integrated Grade IV of Revision 2017 published by Kementerian Pendidikan dan Kebudayaan is relevant to HOTS.
\end{abstract}

\section{Keywords: Bahasa Indonesia main material; higher order thinking skills; thematic- book grade IV}

\section{INTRODUCTION}

Bahasa Indonesia is one of the competencies or subjects that must be followed by students ranging from elementary schools to tertiary institutions. Bahasa Indonesia learning is expected to help students get to know themselves, culture, express ideas, and feelings, participate in communities that use the language, and discover the analytical and imaginative abilities inherent in them. ${ }^{1}$ In essence, learning Bahasa Indonesia is a process of understanding and producing ideas, feelings, messages, information, data, and knowledge for various scientific communication needs both in writing and orally. ${ }^{2}$

\footnotetext{
${ }^{1}$ Thomas Frans, "Pembelajaran Bahasa Dan Sastra Sebagai Penguatan Dan Pemertahanan NilaiNilai Lokal," Jurnal Tahuri $14, \quad$ no. 2017 : 2 (2019, https://ojs3.unpatti.ac.id/index.php/tahuri/article/view/1369.

${ }^{2}$ Haerun Anna, "Pembelajaran Bahasa Indonesia Dalam Konteks Multibudaya," Al-Ta'dib 9, no. 2 (July 1, 2016): 74-91, https://doi.org/10.31332/atdb.v9i2.514.
} 
Bahasa Indonesia learning is implemented based on text. ${ }^{3}$ This learning is vulnerable to make students bored and lazy to read so that Bahasa Indonesia subjects tend to be less liked by students. ${ }^{4}$ Bahasa Indonesia's learning has an essential goal in the development of students themselves.

Bahasa Indonesia learning aims to train students to be able to speak by presenting their ideas creatively and critically. ${ }^{5}$ The presenting of ideas creatively and critically is one of the essential factors in development, also student intelligence. This description illustrates that the ability of Bahasa Indonesia learning is not only based on text. But it can be understood that the ability in Bahasa Indonesia subjects also plays a role as support in learning other subjects.

In elementary school learning, Bahasa Indonesia subject matter is integrated into learning themes that are linked to several other subjects ${ }^{6}$, which is designed in a thematic book. Thematic books are one of the teaching materials that have an important role in the implementation of learning. ${ }^{7}$ The teaching materials have a significant influence on the implementation of learning activities. The learning activities meant are the learning that arranged to improve student activities and learning outcomes. The learning aim is to achieve learning objectives, facilitate students to be actively involved, and hone the reasoning abilities as well as high-level thinking skills of students. ${ }^{8}$ The higher-order thinking skills at elementary school (ES) or madrasah ibtidaiyah (MI) level are priorities

\footnotetext{
${ }^{3}$ Main Sufanti, Pembelajaran Bahasa Indonesia Berbasis Teks: Belajar Dari Ohio Amerika Serikat (Surakarta, Jawa Tengah: FKIP Universitas Muhammadiyah Surakarta, 2017), https://publikasiilmiah.ums.ac.id/xmlui/bitstream/handle/11617/3363/2_Pembelajaran\%20Bahasa\%20Ind onesia\%20Berbasis\%20Teks\%20Belajar\%20Dari\%200hio\%20Amerika\%20Serikat.pdf?sequence=1\&is Allowed=y.

${ }^{4}$ Nina Nurhasanah, "Peranan Bahasa Sebagai Mata Pelajaran Wajib Di Indonesia," Eduscience : Jurnal Ilmu Pendidikan 2, no. $02 \quad$ (February $1, \quad$ 2017), https://ejurnal.esaunggul.ac.id/index.php/EDU/article/view/1830.

${ }^{5}$ Endah Tri Priyatni, Desain Pembelajaran Bahasa Indonesia Dalam Kurikulum 2013 (Jakarta: Bumi Aksara, 2017), 37.

${ }^{6}$ Apri D.S. Krissandi, B. Widharyanto, and Rishe Purnama Dewi, Pembelajaran Bahasa Indonesia Untuk SD: Pendekatan Dan Teknis (Jakarta: Media Maxima, 2017), 6.

7 Arif Widodo et al., "Analisis Konten HOTS dalam Buku Siswa Kelas V Tema 6 'Panas dan Perpindahannya' Kurikulum 2013,” Madrasah: Jurnal Pendidikan dan Pembelajaran Dasar 12, no. 1 (January 7, 2020): 1-13, https://doi.org/10.18860/mad.v12i1.7744.

${ }^{8}$ Widya Pratiwi, "Pengembangan Bahan Ajar Bermuatan High Order Thinking Skill (HOTS) Pada Pembelajaran Tema Persatuan Dalam Perbedaan," vol. 1 (Prosiding Seminar Nasional Unimus, Semarang: Universitas Muhammadiyah Semarang, 2018), https://prosiding.unimus.ac.id/index.php/semnas/article/viewFile/16/17.
} 
to form competent outputs. ${ }^{9}$ This priority confirms with the Ministry of Education and Culture (MOEC) Regulation No. 20 of 2016. This regulation arranges the learning in ES/ MI is directed to develop the ability to think highly or known as Higher Order Thinking Skills (HOTS). The same is true for Bahasa Indonesia subjects, including the subject matter of basic competencies. The high-level thinking ability is expected by students not only to know the material but also to analyze and solve problems related to the material or concept he understood. ${ }^{10}$

In connection with the above description, Permendikbud No. 22 of 2016 explains that one of the 14 learning principles requires students to be able to think at a high level (HOTS). Among them from being told to finding out, from the teacher as a source of learning, to being a variety of learning resources, previously content-based learning to be competency-based, and so forth. ${ }^{11}$ Higher Order Thinking Skills (HOTS) can be understood as the ability to think deeply to conclude an object or problem. Thinking ability can be called HOTS if it fulfills several indicators. These indicators include providing simple explanations, building basic skills, concluding, providing further explanations, as well as determining or managing strategies in problem-solving. ${ }^{12}$

The ability to think at a higher level is a skill in understanding information and data and how to solve problems critically, creatively, and analytically. ${ }^{13}$ Annu, et al., state that high-level thinking is the stage of thinking to train students' cognitive abilities at a higher level. A higher level, namely students, can analyze, evaluate, and provide an assessment of a fact learned. Besides, the student can combine facts and ideas to create something new based on what that has been learned creatively. ${ }^{14}$ Anderson and Krathwohl in

\footnotetext{
${ }^{9}$ Khusnul Fajriyah and Ferina Agustini, “Analisis Keterampilan Berpikir Tingkat Tinggi Siswa SD Pilot Project Kurikulum 2013 Kota Semarang,” Elementary School: Jurnal Pendidikan Dan Pembelajaran Ke-SD-An 5, no. 1 (2018), https://doi.org/10.31316/esjurnal.v5i1.594.

${ }^{10}$ Noven Kusainun, "Relevansi Materi Pokok Matematika Pada Tema 1 Kelas I SD Dengan HOTS (Higher Order Thinking Skills)," Jurnal JPSD (Jurnal Pendidikan Sekolah Dasar) 6, no. 1 (February 25, 2019): 9-15, https://doi.org/10.12928/jpsd.v6i1.14145.

11 Minister of Education and Culture, "Standar Proses Pada Pendidikan Dasar Dan Menengah, Peraturan Menteri Pendidikan Dan Kebudayaan Nomor 22/2016” (MOEC, Indonesia, 2016).

12 Maharani Yuniar, Cece Rakhmat, and Asep Saepulrohman, "Analisis HOTS (High Order Thinking Skills) Pada Soal Objektif Tes Dalam Mata Pelajaran Ilmu Pengetahuan Sosial (IPS) Kelas V SD Negeri 7 Ciamis," E-JURNAL (blog), accessed May 20, 2020, https://www.e-jurnal.com/2017/05/analisishots-high-order-thinking.html.

13 Widodo et al., "Analisis Konten HOTS dalam Buku Siswa Kelas V Tema 6 'Panas dan Perpindahannya' Kurikulum 2013."

${ }^{14}$ Tia Agusti Annuuru, Riche Cynthia Johan, and Mohammad Ali, "Peningkatan Kemampuan Berpikir Tingkat Tinggi Dalam Pelajaran Ilmu Pengetahuan Alam Peserta Didik Sekolah Dasar Melalui
} 
Setyaningsih explained that based on Bloom's Taxonomy thinking skills are divided into two categories, namely lower-order thinking skills (LOTS) consisting of remembering, understanding, and applying and higher-order thinking skills (HOTS) consisting of analysis skills, evaluating, the ability of synthesis, and creating. ${ }^{15}$

Setyaningsih stated that students could master high-level thinking skills if they have mastered low-level thinking. ${ }^{16}$ Regarding this statement, it can be understood that learning requires a gradual process and practice consistently and pay attention to the stages of thinking that are based on Bloom's Taxonomy. HOTS is also at a level above comprehension ability when viewed in Bloom's Taxonomy. ${ }^{17}$

The content standards and assessment standards in the 2013 curriculum were adopted from HOTS-oriented international standards. This step has been done because, according to the results of the PISA study, the competency of students in Indonesia to analyze a problem and information is still very complicated. ${ }^{18}$ Thus, the subject matter has to be oriented to HOTS. Meanwhile, the learning process implemented through problem-based learning. Then, the assessment system has been arranged so that students are not only trained to answer low-level questions (LOTS) such as knowing (C1), understanding (C2), applying (C3), but also higher levels (HOTS) such as analyzing (C4), evaluating (C5) and creating (C6). ${ }^{19}$

HOTS is one of the capabilities needed in the 21 st century. HOTS is needed as a skill in solving problems in an age of rapid scientific and technological development. To face these challenges, students must have at least four competencies consisting of critical thinking skills, high comprehension skills, communication, and collaborative abilities and

Model Pembelajaran Treffinger," Educational Technologia 1, no. 2 (August 1, 2017), https://ejournal.upi.edu/index.php/edutechnologia/article/view/9144.

15 Janer Simarmata and dkk., Pembelajaran STEM Berbasis HOTS Dan Penerapannya (Sumatera Utara: Yayasan Kita Menulis, 2020).

${ }^{16}$ Lilik Setyaningsih and Arta Ekayanti, "Keterampilan Berfikir Siswa SMP Dalam Menyelesaikan Soal Matematika Ditinjau Dari Kemampuan Number Sense," Jurnal Didaktik Matematika 6, no. 1 (April 30, 2019): 28-39, https://doi.org/10.24815/jdm.v6i1.11699.

${ }^{17}$ Simarmata and dkk., Pembelajaran STEM Berbasis HOTS Dan Penerapannya, 27.

18 Subadar Subadar, "Penguatan Pendidikan Karakter (PPK) Berbasis Higher Order Thinking Skills (HOTS)," PEDAGOGIK: Jurnal Pendidikan 4, no. 1 (June 30, 2017), https://www.ejournal.unuja.ac.id/index.php/pedagogik/article/view/9.

19 Auriellya Destya Maharani, "HOTS Pada Assesment Pembelajaran Tematik Muatan Pembelajaran IPA Siswa Sekolah Dasar,” Seminar Nasional Pendidikan Dasar 1, no. 01 (March 30, 2019), http://eproceedings.umpwr.ac.id/index.php/semnaspgsd/article/view/1059. 
creative thinking skills. ${ }^{20}$ From this description, it can be understood how important higher-level thinking skills are. Therefore, the subject matter of the Bahasa Indonesia as one of the contents of subjects in the thematic books must contain content oriented to the development of high-level thinking skills in the cognitive analysis (C4), evaluation (C5), and creative (C6). Based on the background above, it is necessary to research to see whether there is the relevance of HOTS with the subject matter of Bahasa Indonesia in the Thematic Integrated Class IV edition of the 2017 semester I (Theme IV) edition published by the Ministry of Education and Culture.

\section{RESEARCH METHODS}

This article uses a qualitative approach because it can be used to obtain detailed information about the problem to be investigated. ${ }^{21}$ The research method used is descriptive to explain or describe a thing, for example, conditions, conditions, situations, events, activities, and others. ${ }^{22}$ The source of data in research is the subject of where the data can be obtained by researchers. ${ }^{23}$ In this article, the primary data source is in the form of thematic books (teacher and student books) for grade IV SD / MI semester I (one). The data collection technique uses the content analysis method. The content analysis method is a method used to obtain information from documents in the form of records, pictures, sounds, writings, etc. objectively and systematically. ${ }^{24}$ Data analysis techniques collected in the form of writing that form the basis of analysis refers to the 2013 Thematic Curriculum book instruments.

\section{RESULTS AND DISCUSSION}

The high-level thinking skills, if related to the subject matter of Bahasa Indonesia for ES/ MI can be seen from the description of the competency of the subject matter. Then in classroom learning, we can see the learning process that is taking place. Can the teacher adjust the conditions mentioned above in carrying out the teaching and learning process?

\footnotetext{
${ }^{20}$ Yunus Abidin, Pembelajaran Multiliterasi (Sebuah Jawaban Atas Tantangan Pendidikan Abad 21) (Bandung: Refika Aditama, 2015), 23.

${ }^{21}$ Deni Darmawan, Metode Penelitian Kuantitatif (Bandung: Remaja Rosdakarya, 2013), 127.

${ }^{22}$ Hadari Nawawi, Penelitian Terapan (Yogyakarta: Gajah Mada University Press, 2001), 73.

${ }^{23}$ Suharsimi Arikunto, Prosedur Penelitian Suatu Pendektan Praktik (The 6th Revission Edition) (Jakarta: Rineka Cipta, 2013), 172.

${ }^{24}$ Suharsimi Arikunto, Manajemen Penelitian (Jakarta: Rineka Cipta, 2016), 244.
} 
Based on the description above, the writer takes several steps in analyzing. 1) connecting KD with learning objectives; 2) formulating indicators based on Bloom's taxonomy (C4-C6); 3) analyze the suitability of learning activities in teacher and student books; 4) conclude. In the following, the author presents the relevance of the subject matter of Bahasa Indonesia to Higher Order Thinking Skills (HOTS) in the teacher's and fourth-grade students' books in the revised edition of $2017 .^{25}$

Table 1

Five theme in $4^{\text {th }}$ Grade

\section{Theme 1. Beautiful Togetherness}

\begin{tabular}{|c|c|c|c|c|c|}
\hline \multirow[b]{2}{*}{$\begin{array}{l}\text { Sub- } \\
\text { Theme }\end{array}$} & \multirow[b]{2}{*}{ KD } & \multirow[b]{2}{*}{ Indicator } & \multicolumn{2}{|c|}{ Page } & \multirow[b]{2}{*}{ KKO } \\
\hline & & & $\begin{array}{c}\text { Teacher's } \\
\text { Book }\end{array}$ & $\begin{array}{c}\text { Student's } \\
\text { Book }\end{array}$ & \\
\hline 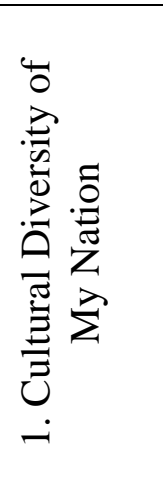 & 3.1 & $\begin{array}{l}\text { a. Identify and present the } \\
\text { main ideas and supporters } \\
\text { in each paragraph of the } \\
\text { written text. } \\
\text { b. Communicating the } \\
\text { cultural, ethnic, and } \\
\text { religious diversity of } \\
\text { classmates in a written and } \\
\text { oral manner systematically. }\end{array}$ & $\begin{array}{c}7 \\
45 \\
61 \\
9 \\
72\end{array}$ & $\begin{array}{c}5 \\
42 \\
67 \\
31\end{array}$ & $\mathrm{C} 4$ \\
\hline 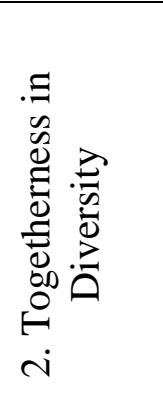 & 3.2 & $\begin{array}{l}\text { a. Analyze the main and } \\
\text { supporting ideas obtained } \\
\text { from oral, written, or visual } \\
\text { texts. } \\
\text { b. Examining the } \\
\text { interconnection between } \\
\text { ideas derived from oral, } \\
\text { written, or visual texts. }\end{array}$ & $\begin{array}{c}83 \\
109 \\
116 \\
135\end{array}$ & $\begin{array}{c}67 \\
76 \\
106 \\
111 \\
127\end{array}$ & $\mathrm{C} 4$ \\
\hline 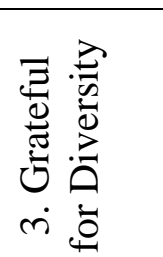 & 3.2 & $\begin{array}{l}\text { Select connections between } \\
\text { ideas derived from oral, } \\
\text { written, or visual texts. }\end{array}$ & $\begin{array}{l}150 \\
171 \\
181 \\
195\end{array}$ & $\begin{array}{l}129 \\
147 \\
160 \\
174\end{array}$ & $\mathrm{C} 4$ \\
\hline
\end{tabular}
2017).

${ }^{25}$ Angi St Anggari and et al., Tematik Terpadu: Buku Guru Dan Siswa (Jakarta: MOEC, Indonesia, 
Theme 2: Always Save Energy

\begin{tabular}{|c|c|c|c|c|c|}
\hline \multirow{2}{*}{$\begin{array}{l}\text { Sub- } \\
\text { Theme }\end{array}$} & \multirow[t]{2}{*}{ KD } & \multirow[t]{2}{*}{ Indicator } & \multicolumn{2}{|c|}{ Page } & \multirow[t]{2}{*}{ KKO } \\
\hline & & & $\begin{array}{c}\text { Teacher's } \\
\text { Book }\end{array}$ & $\begin{array}{c}\text { Student's } \\
\text { Book }\end{array}$ & \\
\hline 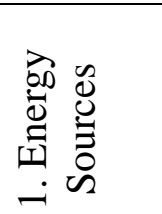 & 3.2 & $\begin{array}{l}\text { Summarize the main ideas } \\
\text { and supporting texts of } \\
\text { visual texts. }\end{array}$ & $\begin{array}{c}6 \\
28 \\
36 \\
50\end{array}$ & $\begin{array}{c}8 \\
25 \\
29 \\
43\end{array}$ & $\mathrm{C} 4$ \\
\hline 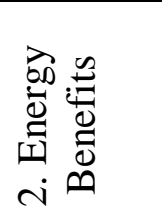 & 3.4 & $\begin{array}{l}\text { Categorize the written } \\
\text { instructions text using two } \\
\text { same and different tools. }\end{array}$ & $\begin{array}{l}60 \\
77 \\
83 \\
98\end{array}$ & $\begin{array}{l}71 \\
75 \\
85\end{array}$ & C6 \\
\hline 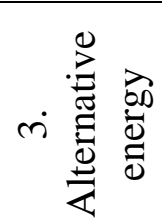 & 3.4 & $\begin{array}{l}\text { Examine the text } \\
\text { instructions for using two } \\
\text { same and different tools. }\end{array}$ & $\begin{array}{l}107 \\
122 \\
130 \\
142\end{array}$ & $\begin{array}{c}99 \\
103 \\
117 \\
131\end{array}$ & $\mathrm{C} 4$ \\
\hline
\end{tabular}

Theme 3: Care for Living Things

\begin{tabular}{|c|c|c|c|c|c|}
\hline \multirow{2}{*}{$\begin{array}{l}\text { Sub- } \\
\text { Theme }\end{array}$} & \multirow[t]{2}{*}{ KD } & \multirow[t]{2}{*}{ Indicator } & \multicolumn{2}{|c|}{ Page } & \multirow[t]{2}{*}{ KKO } \\
\hline & & & $\begin{array}{c}\text { Teacher's } \\
\text { Book }\end{array}$ & $\begin{array}{c}\text { Student's } \\
\text { Book }\end{array}$ & \\
\hline 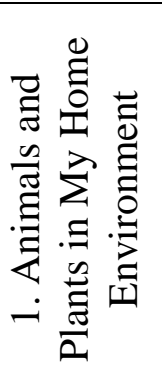 & 3.3 & $\begin{array}{l}\text { a. The design has written } \\
\text { questions using standard } \\
\text { vocabulary based on the } \\
\text { observed images } \\
\text { b. Analyze the characteristics } \\
\text { of good questions based on } \\
\text { pictures. }\end{array}$ & 34 & $\begin{array}{c}4 \\
6 \\
23\end{array}$ & C6 \\
\hline 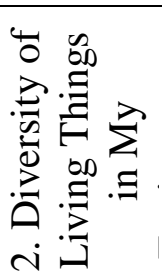 & 3.3 & $\begin{array}{l}\text { a. Group questions based on } \\
\text { animal characteristics. } \\
\text { b. Rearranges how to write a } \\
\text { report on the results of the } \\
\text { interview properly. }\end{array}$ & 102 & $\begin{array}{l}50 \\
69 \\
72 \\
89\end{array}$ & C6 \\
\hline
\end{tabular}




\begin{tabular}{|c|c|c|c|c|c|}
\hline 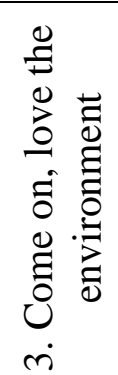 & 3.3 & $\begin{array}{l}\text { a. Share information about the } \\
\text { utilization of biological } \\
\text { natural resources for the } \\
\text { welfare of the community. } \\
\text { b. Supporting greening as an } \\
\text { effort to preserve natural } \\
\text { resources. }\end{array}$ & 131 & 122 & $\mathrm{C} 5$ \\
\hline
\end{tabular}

Theme 4: Various Works

\begin{tabular}{|c|c|c|c|c|c|}
\hline \multirow[b]{2}{*}{$\begin{array}{l}\text { Sub- } \\
\text { Theme }\end{array}$} & \multirow[b]{2}{*}{ KD } & \multirow[b]{2}{*}{ Indicator } & \multicolumn{2}{|c|}{ Page } & \multirow[b]{2}{*}{ KKO } \\
\hline & & & $\begin{array}{l}\text { Teacher's } \\
\text { book }\end{array}$ & $\begin{array}{l}\text { Student's } \\
\text { Book }\end{array}$ & \\
\hline \multirow{8}{*}{ 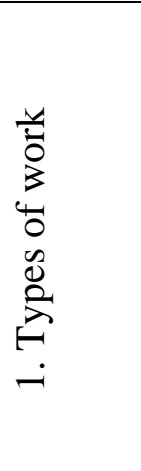 } & \multirow[t]{8}{*}{3.5} & a. Compose examples of & 9 & 5 & C6 \\
\hline & & activities that can maintain & 30 & 11 & \\
\hline & & the balance and & 39 & & \\
\hline & & $\begin{array}{l}\text { sustainability of natural } \\
\text { resources completely. }\end{array}$ & 55 & 31 & $\mathrm{C} 4$ \\
\hline & & b. Analyze the character's & & & \\
\hline & & attitude in the story and & & & \\
\hline & & relate it to the values of & & & \\
\hline & & & & & \\
\hline \multirow{6}{*}{ 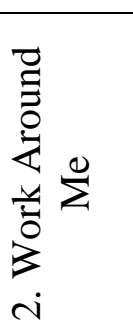 } & \multirow[t]{6}{*}{3.5} & \multirow{6}{*}{$\begin{array}{l}\text { a. Assess the whole story } \\
\text { b. Comparing the properties } \\
\text { of figures using traditional } \\
\text { and modern tools. } \\
\text { c. Assess the moral message } \\
\text { of a story }\end{array}$} & 80 & 52 & C5 \\
\hline & & & 105 & 54 & C5 \\
\hline & & & 110 & & \\
\hline & & & 127 & 90 & C5 \\
\hline & & & & & \\
\hline & & & & & \\
\hline \multirow{6}{*}{ 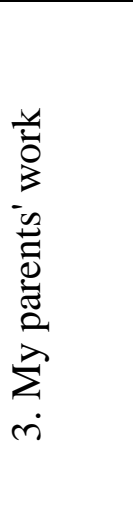 } & \multirow[t]{6}{*}{3.5} & a. Design predictions about & 137 & 97 & C6 \\
\hline & & story. & 158 & 99 & $\mathrm{C} 4$ \\
\hline & & $\begin{array}{l}\text { b. Analyzing the type of } \\
\text { work-related to social } \\
\text { culture in their region. }\end{array}$ & 178 & 114 & C6 \\
\hline & & c. Building personal opinions & & & \\
\hline & & about the contents of & & & \\
\hline & & $\begin{array}{l}\text { literary books (stories, } \\
\text { fables, etc.). }\end{array}$ & & & \\
\hline
\end{tabular}


Theme 5: My Heroes

\begin{tabular}{|c|c|c|c|c|c|}
\hline \multirow[b]{2}{*}{$\begin{array}{c}\text { Sub- } \\
\text { Theme }\end{array}$} & \multirow[b]{2}{*}{ KD } & \multirow[b]{2}{*}{ Indicator } & \multicolumn{2}{|c|}{ Page } & \multirow[b]{2}{*}{ KKO } \\
\hline & & & $\begin{array}{l}\text { Teacher's } \\
\text { book }\end{array}$ & $\begin{array}{c}\text { Student's } \\
\text { Book }\end{array}$ & \\
\hline 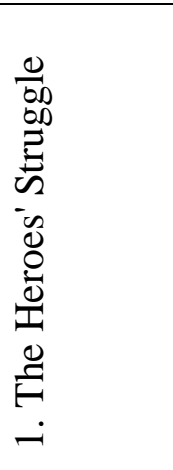 & 3.7 & $\begin{array}{l}\text { a. Exploring new } \\
\text { knowledge contained in } \\
\text { nonfiction texts (the } \\
\text { history of Hinduism, } \\
\text { Buddhism, and Islam and } \\
\text { its influence on the } \\
\text { surrounding community) } \\
\text { b. Compile an experiment } \\
\text { report about light. }\end{array}$ & 12 & 5 & $\mathrm{C} 4$ \\
\hline 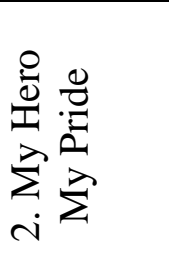 & 3.8 & $\begin{array}{l}\text { a. Compile experimental } \\
\text { reports about mirrors and } \\
\text { lights. } \\
\text { b. Analyzing information } \\
\text { from the Pattimura text. }\end{array}$ & $\begin{array}{c}93 \\
115\end{array}$ & $\begin{array}{l}57 \\
79\end{array}$ & $\begin{array}{l}\text { C6 } \\
\text { C4 }\end{array}$ \\
\hline 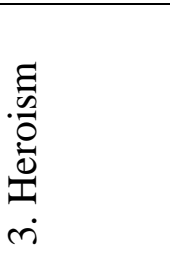 & & $\begin{array}{l}\text { Make experiments with } \\
\text { concave mirrors, convex } \\
\text { mirrors and data mirrors }\end{array}$ & 128 & 99 & C6 \\
\hline
\end{tabular}

Based on the results of the analysis of the teacher and student books, there are several subject matter materials for the fourth-grade semester Bahasa Indonesia in Thematic books (teacher and student books) consisting of: main and supporting ideas; the relationship between the main ideas and supporters in oral, written or visual texts; written instructions text; written questions using standard vocabulary; report the results of interviews systematically; information about the utilization of living natural resources; analysis of the character's attitude in the story; assess the whole story; give opinions about the contents of literary books (stories, fables, etc.); comparing character traits; moral message in a story; and nonfiction text. From the above subject matter, 27 indicators contain HOTS, which are five indicators in theme one consisting of C4 and C6.

Figure 1 is a comparison chart of the number of indicators containing HOTS in each theme. 


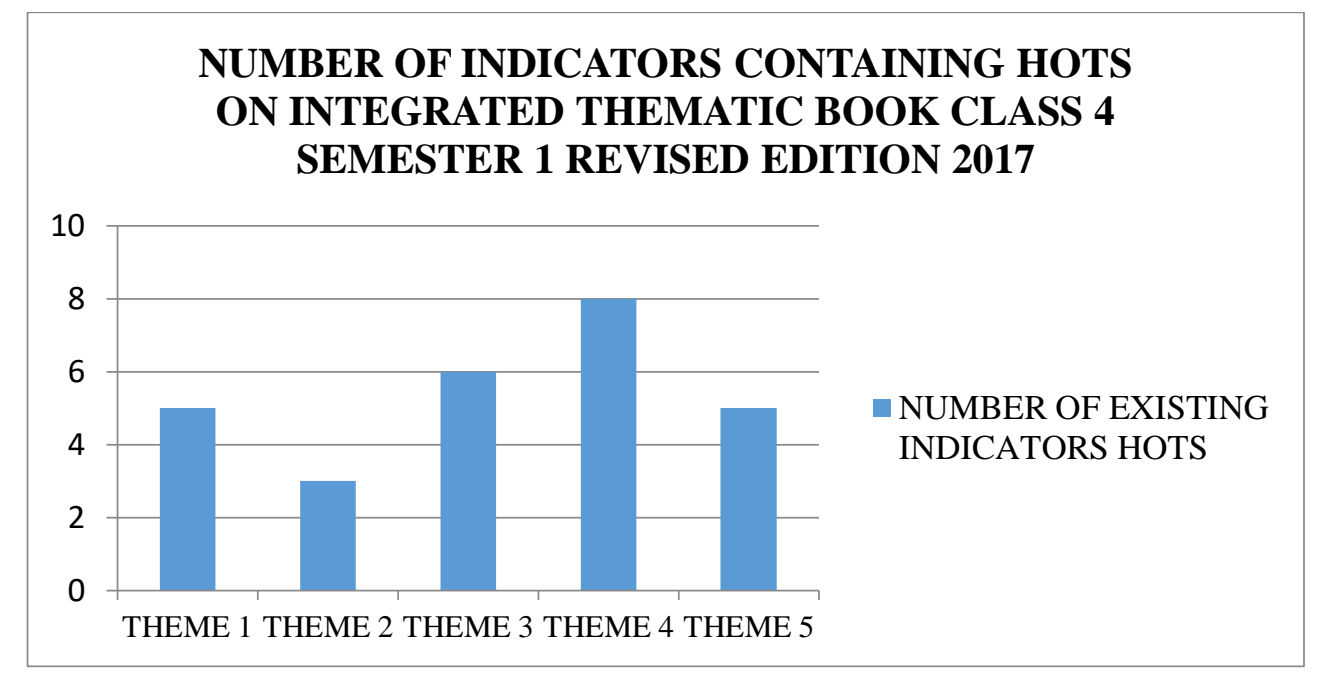

Figure 1

A Comparison Chart of The Number of Indicators Containing HOTS in Five Themes

Based on the diagram, it can be seen that five themes contain more than one indicator that contains HOTS. In my opinion, the subject matter of the Bahasa Indonesia contained in the 2017 revised edition thematic book grade IV is already relevant to HOTS. This data is also seen in learning activities (teacher and student books) that require students to be able to think at a high level (HOTS), and the learning taught is contextual.

Nevertheless, several obstacles might occur in the implementation of the Bahasa Indonesia learning process in the classroom, both from the teacher or students. Such as, the lack of the teacher lies in his expertise in managing and mastering teaching materials. Then, learning media inadequate. The activities teacher were sometimes too fixated on the material already in the textbook without analyzing the accuracy of the sequence of teaching materials with students. So learning is not following the expected goals. The lack of students is influenced by two factors, namely internal and external. ${ }^{26}$ Internal factors consist of a person's natural body. For example, vision, hearing, and so forth. Meanwhile, external factors are influenced by the student's environment. Like the climate and learning facilities available at home/school.

${ }^{26}$ Singgih Gunarsa and Yulia Singgih Gunarsa, Psikologi Perkembangan Anak Dan Remaja (Jakarta: Gunung Mulia, 2008), 178. 


\section{CONCLUSION}

Based on the results of teacher and student book analysis, it can be concluded that overall the primary Bahasa Indonesia material contained in the revised version of the fourth-grade thematic book published by the Ministry of Education and Culture is already relevant to HOTS. Students are also required to think at a high level; in this case, the teacher only acts as a facilitator and is not the only source of learning in the learning process. Furthermore, in learning, students are required to be able to communicate well, collaboratively, creatively, and think critically. Even so, there are still deficiencies that need to be addressed in an educational institution, including Bahasa Indonesia for ES/ MI teaching materials delivered by teachers must be following the level of student development. In this case, teaching materials are needed to support the achievement of learning objectives that have been determined and arranged in a particular order that forms a sequence of teaching materials. However, a few teachers did not understand and did not know about the sequence of teaching materials that are appropriate to the development of their students. The teachers need sufficient training to be given suitable to carry out their duties properly by established educational goals.

\section{REFERENCES}

Abidin, Yunus. Pembelajaran Multiliterasi (Sebuah Jawaban Atas Tantangan Pendidikan Abad 21). Bandung: Refika Aditama, 2015.

Anggari, Angi St, and et al. Tematik Terpadu: Buku Guru Dan Siswa. Jakarta: MOEC, Indonesia, 2017.

Anna, Haerun. "Pembelajaran Bahasa Indonesia Dalam Konteks Multibudaya." AlTa'dib 9, no. 2 (July 1, 2016): 74-91. https://doi.org/10.31332/atdb.v9i2.514.

Annuuru, Tia Agusti, Riche Cynthia Johan, and Mohammad Ali. "Peningkatan Kemampuan Berpikir Tingkat Tinggi Dalam Pelajaran Ilmu Pengetahuan Alam Peserta Didik Sekolah Dasar Melalui Model Pembelajaran Treffinger." Educational Technologia 1, no. 2 (August 1, 2017). https://ejournal.upi.edu/index.php/edutechnologia/article/view/9144.

Arikunto, Suharsimi. Manajemen Penelitian. Jakarta: Rineka Cipta, 2016.

_. Prosedur Penelitian Suatu Pendektan Praktik (The 6th Revission Edition). Jakarta: Rineka Cipta, 2013.

Darmawan, Deni. Metode Penelitian Kuantitatif. Bandung: Remaja Rosdakarya, 2013.

Fajriyah, Khusnul, and Ferina Agustini. "Analisis Keterampilan Berpikir Tingkat Tinggi Siswa SD Pilot Project Kurikulum 2013 Kota Semarang.” Elementary School: 
Jurnal Pendidikan Dan Pembelajaran Ke-SD-An 5, no. 1 (2018). https://doi.org/10.31316/esjurnal.v5i1.594.

Frans, Thomas. "Pembelajaran Bahasa Dan Sastra Sebagai Penguatan Dan Pemertahanan Nilai-Nilai Lokal." Jurnal Tahuri 14, no. 2 (2017): 8-19, https://ojs3.unpatti.ac.id/index.php/tahuri/article/view/1369.

Gunarsa, Singgih, and Yulia Singgih Gunarsa. Psikologi Perkembangan Anak Dan Remaja. Jakarta: Gunung Mulia, 2008.

Krissandi, Apri D.S., B. Widharyanto, and Rishe Purnama Dewi. Pembelajaran Bahasa Indonesia Untuk SD: Pendekatan Dan Teknis. Jakarta: Media Maxima, 2017.

Kusainun, Noven. "Relevansi Materi Pokok Matematika Pada Tema 1 Kelas I SD Dengan HOTS (Higher Order Thinking Skills)." Jurnal JPSD (Jurnal Pendidikan Sekolah Dasar) 6, no. 1 (February 25, 2019): 9-15. https://doi.org/10.12928/jpsd.v6i1.14145.

Maharani, Auriellya Destya. "HOTS Pada Assesment Pembelajaran Tematik Muatan Pembelajaran IPA Siswa Sekolah Dasar." Seminar Nasional Pendidikan Dasar 1, no. $01 \quad$ (March $\quad 30$, 2019). http://eproceedings.umpwr.ac.id/index.php/semnaspgsd/article/view/1059.

Minister of Education and Culture. "Standar Proses Pada Pendidikan Dasar Dan Menengah, Peraturan Menteri Pendidikan Dan Kebudayaan Nomor 22/2016." MOEC, Indonesia, 2016.

Nawawi, Hadari. Penelitian Terapan. Yogyakarta: Gajah Mada University Press, 2001.

Nurhasanah, Nina. "Peranan Bahasa Sebagai Mata Pelajaran Wajib Di Indonesia." Eduscience: Jurnal Ilmu Pendidikan 2, no. 02 (February 1, 2017). https://ejurnal.esaunggul.ac.id/index.php/EDU/article/view/1830.

Pratiwi, Widya. "Pengembangan Bahan Ajar Bermuatan High Order Thinking Skill (HOTS) Pada Pembelajaran Tema Persatuan Dalam Perbedaan," Vol. 1. Semarang: Universitas Muhammadiyah Semarang, 2018. https://prosiding.unimus.ac.id/index.php/semnas/article/viewFile/16/17.

Priyatni, Endah Tri. Desain Pembelajaran Bahasa Indonesia Dalam Kurikulum 2013. Jakarta: Bumi Aksara, 2017.

Setyaningsih, Lilik, and Arta Ekayanti. "Keterampilan Berfikir Siswa SMP Dalam Menyelesaikan Soal Matematika Ditinjau Dari Kemampuan Number Sense." Jurnal Didaktik Matematika 6, no. 1 (April 30, 2019): 28-39. https://doi.org/10.24815/jdm.v6i1.11699.

Simarmata, Janer, and dkk. Pembelajaran STEM Berbasis HOTS Dan Penerapannya. Sumatera Utara: Yayasan Kita Menulis, 2020.

Subadar, Subadar. "Penguatan Pendidikan Karakter (PPK) Berbasis Higher Order Thinking Skills (HOTS)." PEDAGOGIK: Jurnal Pendidikan 4, no. 1 (June 30, 2017). https://www.ejournal.unuja.ac.id/index.php/pedagogik/article/view/9.

Sufanti, Main. Pembelajaran Bahasa Indonesia Berbasis Teks: Belajar Dari Ohio Amerika Serikat. Surakarta, Jawa Tengah: FKIP Universitas Muhammadiyah Surakarta, 
https://publikasiilmiah.ums.ac.id/xmlui/bitstream/handle/11617/3363/2_Pembela jaran\%20Bahasa\%20Indonesia\%20Berbasis\%20Teks\%20Belajar\%20Dari\%20O hio\%20Amerika\%20Serikat.pdf?sequence $=1 \&$ isAllowed $=$.

Widodo, Arif, Dyah Indraswati, Radiusman Radiusman, Umar Umar, and Nursaptini Nursaptini. "Analisis Konten HOTS dalam Buku Siswa Kelas V Tema 6 'Panas dan Perpindahannya' Kurikulum 2013." Madrasah: Jurnal Pendidikan dan Pembelajaran Dasar 12, no. 1 (January 7, 2020): 1-13. https://doi.org/10.18860/mad.v12i1.7744.

Yuniar, Maharani, Cece Rakhmat, and Asep Saepulrohman. “Analisis HOTS (High Order Thinking Skills) Pada Soal Objektif Tes Dalam Mata Pelajaran Ilmu Pengetahuan Sosial (IPS) Kelas V SD Negeri 7 Ciamis.” E-JURNAL (blog). Accessed May 20, 2020. https://www.e-jurnal.com/2017/05/analisis-hots-high-order-thinking.html. 
Relevance of Bahasa Indonesia...

96 | Al-Bidayah, Volume 12, Number 1, June 2020 